\title{
FINANZAS MUNICIPALES Y PATRICIADO URBANO. VALENCIA A FINALES DEL TRESCIENTOS
}

\author{
RAFAEL NARBONA VIZCAÍNO
}

\author{
SUMARIO
}

I. La administración financiera y contable. - II. La financiación del abastecimiento frumentario. - III. La deuda pública: los censales municipales. - IV. La fiscalidad municipal: el arrendamiento de impuestos.

La hacienda municipal de época foral y las bases financieras de las instituciones locales han constituido tan sólo un soslayado objeto de estudio en el largo periplo recorrido por la historiografía valenciana. A las primeras y genéricas aproximaciones de Francisco García de Cáceres ' siguieron algunas acotaciones sobre impuestos locales o generales ${ }^{2}$, y más tarde algunos análisis pormenorizados sobre ámbitos cronológicos y espaciales precisos ${ }^{3}$. La aclara-

' Cfr. Impuestos de la ciudad de Valencia durante la época foral, Valencia, 1909.

2 Cfr. J. Ma DOÑATE, Sobre el General del "tall del drap o del quarter», "BSCC», 47 (Castellón, 1971), pp. 69-76; Ma. Rosa MUÑoz ha tratado algunos impuestos de la hacienda real: Bases municipales de un impuesto general: las Cortes de Valencia de 1329, "Saitabi», 33 (Valencia, 1983), pp. 85-95 y Aproximación al sistema impositivo de la Generalidad: el "tall del drap» en el área alicantina (siglos XIV y XV), "Anales de la Universidad de Alicante. Historia Medieval», 4-5 (Alicante, 1986) pp. 175-189. También cfr. P. LÓPEZ ELUM, El impuesto del morabatí, su base económica y sus aplicaciones demográficas. Datos para su estudio (siglos XIII-XVIII). Resumen de tesis doctoral. Anales de la Universidad de Valencia, Valencia, 1972.

3 Cfr. en este sentido los trabajos de Antoni Furió-Ferran García, La economía municipal de Alzira a fines del siglo XIV según un libro de cuentas de 1380-1381. En La ciudad bispánica durante los siglos XIII al XVI, Madrid, 1985, tomo II pp. 1611-1633; Pau VICIANO NAVARRO, Ingrés $i$ despesa d'una vila valenciana del quatrecents. Les finances municipals de Castelló de la Plana (1426-1427), "BSCC», 66 (Castellón, 1990) pp. 635-664; Enric GuINOT, La gestió dels llocs de reialenc: les rendes de la batllia de Corbera (1432-1465), 
ción y la sintética constatación de las genéricas pautas orgánico-funcionales de la hacienda municipal catalana en época medieval en la obra de J. $\mathbf{M}^{2}$. Font y Rius, y la existencia de singulares estudios para el marco geográfico peninsular o valenciano más inmediato, nos permiten afirmar con toda seguridad que las mismas bases financieras argumentadas para las instituciones locales forales son perfectamente traspolables y homologables a las de la ciudad de Valencia '. Así se corrobora en los pioneros estudios iniciados por $\mathrm{E}$. Belenguer sobre la Valencia de Fernando el Católico, y en los más recientes de R. Ferrero sobre el reinado de Carlos I'. Pese a ello la impresión de conjunto parece evidenciar una completa desconexión entre las metodologías y contenidos de estudio propios de la historia de las instituciones (hacienda municipal) y de la historia económica y social (finanzas, fiscalidad, etc.), tal como si sus respectivos objetos de estudio constituyeran compartimentos estancos deslindados. El fenómeno se percibe incluso en aquellos trabajos donde todos los aspectos reciben un tratamiento conjunto, aunque eso sí individualizado en capítulos o apartados. La correlación historiográfica entre instituciones y finanzas parece no querer entender que su inevitable marco de concreción es la historia del poder, reflejada en última instancia en la misma historia de la sociedad.

Los estudios hacendísticos se han decantado en Valencia ciudad hacia las cronologías de estudio más contínuas, propias de las fuentes documentales que

«Economia Agrària i Història Local. I Assemblea d'Història de la Ribera» (València, 1981), pp. 291-306; F.C. FRADEJAS-P. GARCí LlAMAZARES, El régimen municipal de Onda a mediados del siglo XV, "Butlletí del Centre d'Estudis Municipals d'Onda", 2 (Onda, diciembre 1988), pp. 7-88; A de BeLTRAN, L'economia municipal de Vila-real en 1362-1363 segons un llibre de claveria, "I Congrés d'Història i Filologia de la Plana» (Nules-Castellón, 1990), pp. 131-139.

${ }^{4}$ Cfr. J. M'. FONT Y RIUS, La administración financiera en los municipios medievales catalanes, En Historia de la Hacienda española (épocas antigua y medieval). Homenaje al profesor Garcia de Valdeavellano, Madrid, 1982, pp. 107-231. También en el mismo volumen los trabajos de B. PALACIOS-M.I. FALCÓN, Las haciendas municipales de Zaragoza a mediados del siglo XV (1440-1472), pp. 543-606; de D. MENJOT, Administración de las baciendas locales urbanas: el ejemplo de la ciudad de Murcia desde el año 1266 basta mediados del siglo XV, pp. 449-482 o su obra Fiscalidad y sociedad. Los murcianos y el impuesto en la Baja Eclad Media, Murcia, 1986; de Ch. GuILlERÉ, Diners, poder i societat a la Girona del segle XIV, Girona, 1984; y de D. BERNABÉ GIL, Hacienda y mercado urbano en la Oribuela foral moderna, Alicante, 1989.

' Cfr. E. Belenguer, València en la crisi del segle XV, Barcelona, 1976. Una breve introducción al tema, del mismo autor, puede hallarse en La evolución político-económica del municipio valenciano durante el siglo XV: del Compromiso de Caspe a las Germanias, "IX Congreso de Historia de la Corona de Aragón», Nápoles, 1982, II, pp. 377-391. También de R. FERRERO MICÓ, La bacienda municipal de Valencia durante el reinado de Carlos $V$, Valencia, 1987. 
presentan una regularidad ejemplar, lo que justifica en última instancia la proliferación de investigaciones desde finales del siglo XV y su continuidad para toda la época moderna, independientemente de la progresiva densificación de la administración y de la configuración del estado desde los últimos tiempos medievales. Salvo los antecedentes elaborados y descritos por E. Belenguer para todo el Cuatrocientos las finanzas de Valencia ciudad en el siglo XIV son completamente desconocidas. Precisamente en esa centuria los consejos municipales orgánicos de las embrionarias instituciones locales se dotaban de rudimentarios mecanismos financieros y fiscales -como poderes autónomos- mediante delegación o cesión del poder real ${ }^{\circ}$.

Por el contrario, los registros contables de la Claveria comuna y la Claveria censals conservados en el Archivo Municipal de Valencia constituyen una documentación lo suficientemente valiosa para abordar de forma específica su estudio, sobre todo porque los Manuals de Consells conservados desde 1306 permiten contrastar los datos contables al tiempo que dejan entrever la progresiva configuración de la maquinaria institucional y administrativa. Ambas claverías vertebraban su gestión con dos tipos documentales: los manuals d'albarans y los llibres de comptes'. A pesar de su regularidad y conservación la discontinuidad cronológica es lo suficientemente importante para no hacer viable una informatización que reconstruya pormenorizadamente toda la contabilidad. Pese a ello el objeto de estudio que se pretende focalizar y subrayar es la conjunción entre la oligarquía patricia y las finanzas locales. Ciertos linajes ciudadanos monopolizaban el poder municipal cuando del mismo se derivaban cruentas luchas políticas. Los Marrades o los Suau entre otros se perpetuaron en

${ }^{6}$ Cfr. los distintos trabajos de J. M' FonT RuUs, pero especialmente Orígenes del régimen municipal de Cataluña, "AHDE», 16 (Madrid, 1945), pp. 389-529 y 17 (1946), pp. 229-585; El desarrollo general del Derecho en los territorios de la Corona de Aragón (siglos XII-XIV), "VII Congreso de Historia de la Corona de Aragón», Barcelona, 1962, pp. 289-326 y Valencia y Barcelona en los origenes de su régimen municipal, en «Estudios Jurídicos en Homenaje al Profesor Santa Cruz Tejeirom, Valencia, 1974, pp. 291-316.

' En ocasiones los libros de ambas claverías están encuadernados conjuntamente pero individualizan en su interior la contabilidad censal de la común. Así ocurre desde el volumen séptimo en adelante mientras que entre el primero y el sexto sólo se reproduce la contabilidad censal. La primera serie posee la signatura " $N$ " y se conserva con cierta regularidad y registros anuales desde 1399-1400, la segunda con la signatura "O" recoge de forma individualizada los libros de Claveria Comuna aunque con escasa continuidad cronológica (sólo se conservan para el siglo XIV los volúmenes de 1365, 1391 y 1393). Las informaciones de los llibres de comptes en cualquiera de las dos claverías suman las cantidades consignadas mientras que los otros se limitan a copiar los pagos individualizados. La indisolubilidad de formato se mantiene en los registros de albaranes pero los volúmenes de la serie "J" desde 1351 recogen los de la Claveria Comuna, y los de la serie "I» agrupan los de la Claveria Censal desde 1367. 
las magistraturas municipales al tiempo que proyectaron sus intereses políticoeconómicos sobre las bases financieras del municipio. La comparación de su acción política y su proyección sobre la administración pone de manifiesto la íntima relación entre el poder y las finanzas *. El fenómeno se puede rastrear en el estricto control político a que fueron sometidas las magistraturas administrativas y contables, en la financiación del abastecimiento frumentario, en la percepción de deuda pública municipal, o en los mismos mecanismos de recaudación de la fiscalidad municipal.

\section{LA ADMINISTRACIÓN FINANCIERA Y CONTABLE.}

La máxima representación institucional del poder ciudadano estaba constituida desde 1245 por los Jurats y su consejo de gobierno que capitalizaban la potestad política del municipio en el plano ejecutivo y deliberativo. De forma inmediata a su configuración institucional se consolidaba todo un cuerpo facultativo de magistraturas dedicadas a la regulación de las actividades socio-económicas ciudadanas. Más de cuarenta oficiales de muy diversa índole ejercieron el control de las diferentes áreas de poder donde se cristalizaban puntualmente las actuaciones políticas del gobierno ciudadano. El conjunto de estos cargos públicos era elegible anualmente a lo largo de las principales festividades del año salvo excepciones bienales o trienales de distintas figuras administrativas. Todas ellas estaban vinculadas orgánicamente a la esfera del poder municipal en una clara subordinación respecto a los Jurats, actuando delegadamente sobre parcelas específicas de la vida urbana por comisión de los mismos, ateniéndose a sus decisiones, ordenanzas e indicaciones cuando aquellos no coparticipaban directamente en su actuación y regimiento.

Entre esta larga nómina de magistraturas y según su proyección socioinstitucional cabría diferenciar tres grupos homogéneos. El primero tendría un claro carácter judicial y comprendería al Justicia Criminal, Justicia Civil, Justicia de trescents sous, Mostassaf, Tribunal de los aemprius, y los Inquisidors contra oficials de la ciutat, cuya progresiva configuración se alargaría a lo largo de un denso proceso ". Un segundo grupo lo configurarían las magistraturas de

${ }^{8}$ Al respecto cfr. Y. BAREL, La ciudad medieval. Sistema social-sistema urbano, Madrid, 1980, pp. 271-278.

"Sobre el justiciazgo valenciano Cfr. P. PÉREZ García, Origen y configuración de una magistratura urbana de la Valencia foral: el justicia criminal, "Estudis», 13 (Valencia, 1988), pp. 21-73. Sobre el ejecutivo valenciano, cfr. mis trabajos Valencia medieval. Institución política y proyecto social, «Millars», 12 (Castellón, 1988-1989), pp. 34-41 y Origenes sociales de los tres estamentos ciudadanos en valencia medieval, «Estudis», 16 (Valencia, 1990), pp. 7-30. 
talante emimentemente social entre las que quedarían comprendidas los Curadors d'òrfens, el Procurador dels miserables, el Afermamossos o Afermavagabunds, e incluso el mismo patronazgo filantrópico que sobre los hospitales medievales ejercía el ejecutivo municipal ". El resto de oficialías ciudadanas quedarían agrupadas por su capacitación administrativa. Las crecientes y diversificadas necesidades del poder local obligaron a densificar desde mediados de la centuria el aparato de gobierno local, y a dotar de mayor complejidad la estructura burocrática municipal con el objetivo funcional de fiscalizar las múltiples acciones de gobierno surgidas del poder político. El reforzamiento de una autoridad pública desde las revitalizadas bases romanistas conllevaba la proliferación de actos administrativos, y por tanto una mayor presencia en la vida política de las tareas y funciones propias de magistraturas técnicas. En torno a este tercer grupo de instituciones proliferarían los intereses políticos ciudadanos, que proyectaron su atención sobre las fórmulas de elección, sorteo y duración del ejercicio de las oficialías, intentando a toda costa mediatizar la perpetuación incondicional de determinados individuos o facciones partidistas, mientras que como resultado de todas esas mutaciones se iban configurando los perfiles y atribuciones de cada una de las instituciones. La interdependencia de las distintas oficialías y la articulación de todo el engranaje jurisdiccional del aparato político de la municipalidad dejaron siempre en manos de los ciutadans de parròquies todas las prerrogativas de gobierno, puesto que en ellos residía en última instancia el control de las fórmulas de acceso a la Juradería y a todas las magistraturas ".

1. El Racional. Desde su creación constituye un cargo administrativo dedicado a la gestión financiera y contable del municipio que también tenía encomendada la misión de cobrar las deudas de que era acreedor, sus rentas y

10 Sobre la proyección social de estas instituciones cfr. R. NARBONA, Pueblo, poder y sexo. Valencia medieval (1306-1420), Valencia, 1992, pp. 64-68.

"Un análisis detallado y profundo del ejercicio del poder municipal evidencia dos tendencias político-institucionales conjugadas en su misma conformación: la búsqueda constante de un equilibrio de poder entre todos los estamentos ciudadanos y la mediatización del mismo, primero a través del sistema electoral para la provisión de cargos y después por la injerencia monárquica en detrimento de la autonomía ciudadana. Cfr. $\mathrm{R}$. NARbona Vizcaíno, Valencia municipio medieval. Poder político y luchas ciudadanas (1239-1418). En prensa. El interés del ejecutivo por los cargos administrativos se percibe en la modulación reglamentista de las fórmulas de acceso, regiduría y duración de las oficialías, pero se constata en extremo cuando las luchas de bandos colapsan la administración urbana y los titulares de los cargos son depuestos y sustituidos directamente por el partido prepotente (por ejemplo el Escrivà del Consell, Racional, Sindic, y los Advocats en 1402,1406 o 1412). 
sisas $^{12}$. Es por excelencia el oficial encargado de examinar su gestión, disfrutando de capacidad suficiente para admitir o rechazar las diferentes partidas. Pesentaba con una relación escriturada el balance administrativo a la máxima jerarquía del poder local (los Jurats). El Racional controla los ingresos y gastos a través de oficiales subordinados cada uno de los cuales gestionaba una contabilidad específica: la claveria comuna, la claveria censals, los Instadors del quitament, el Sotsobrer de Murs i Valls, i el Administrador de la Lonja Nueva.

Durante la primera época de su existencia el Racional hacía las veces de un técnico contable, auténtico interventor o fiscalizador de cuentas carente de cualquier tipo de responsabilidad política. Por esta razón, la provisión del oficio estaba encomendada al Consell y su ejercicio tenía carácter vitalicio. No obstante, el sistema electoral utilizado para proveerlo y el tiempo de duración de su regencia experimentarían distintas variaciones, perfilándose progresivamente la magistratura con una serie de indicativos indicios:

En 1386 son los Jurats quien con veinte prohombres designados por ellos mismos nominaban a una serie de candidatos, que tras la oportuna votación nombraban directamente al titular del oficio. En 1389 la nominación es idéntica pero se estipuló que la votación sería secreta, y que en ella participaría el conjunto de consellers. El candidato más votado detentaría el cargo de Racional por tres años consecutivos. En 1396 se estipulaba que el titular del oficio ostentara el puesto por un período de tiempo indeterminado, es decir, hasta que el Consell decidiese lo contrario. En 1408 los Jurats siguen eligiendo a un grupo de prohombres para presentar aspirantes aptos al cargo pero este colectivo sólo nominará a cuatro candidatos, que tras votación secreta del Consell plenario adjudicaría el puesto por mayoría. Desde 1415 el Racional electo no podrá desarrollar el cargo más de dos o tres años consecutivos y tras el período estipulado de regencia será obligatoria la renovación del titular. En 1418 serán los Jurats quienes junto a los Advocats de la ciutat y un grupo de prohombres nominarán una lista de aspirantes que sujeta a votación emitirá el nombre del titular".

La ininterrumpida formalización del procedimiento utilizado para adjudicar el cargo y las restricciones al tiempo de su ejercicio por un mismo titular está en estrecha relación con la progresiva importancia que fue adquiriendo en el seno del municipio. Pero además se observa la absoluta vinculación del oficio al ejecutivo por la elaboración consciente de un sistema de propuestas de candidatos para proveer el puesto a partir de nominaciones eminentemente técnico-

12 También constituye un tribunal. Al respecto Cfr. AMV, Libros judiciales del Racional y Jurados que con la signatura "PP» se conservan desde 1349.

${ }^{13}$ Cfr. AMV, Manuals de Consells A-19 (1389, mayo 8) A- 21 (1396, junio 23) A-24 (1408, junio 23) A-25 (1415, marzo 14) A-26 (1418, marzo 14). 
políticas, que proceden en exclusiva del ejecutivo (Jurats), las cuales serán sometidas a votación general de todo el cuerpo consultivo (Consell). Al mismo tiempo se detecta una tendencia a la máxima concreción del tiempo en que se prolonga su ejercicio, precisándose y restringiéndose cada vez más su duración (carácter vitalicio en principio, indefinido después o trienal-bienal en última instancia). El conjunto de reformas sería simultáneo a toda una serie de medidas de reestructuración político-electoral en la organización de los métodos de acceso al poder municipal, así como a la progresiva delimitación de las atribuciones de las magistraturas. En relación directa con todas estas mutaciones habría que resaltar el inmediato inicio de una segunda época en la caracterización de la magistratura. La introducción de la ceda como sistema de provisión de puestos en la Juradería dotaría de poderes políticos al Racional. En adelante éste sería el encargado de confeccionar en nombre del rey la lista de candidatos (doce caballeros y doce ciudadanos) que optarían anualmente a las seis plazas de Jurats, quien en cualquier caso podría aceptar, corregir o alterar su contenido. Una vez confeccionada esta ceda o lista de aspirantes se efectuaría un sorteo para adjudicar las seis magistraturas del ejecutivo. En este nuevo marco electoral introducido por Alfonso $\mathrm{V}$ en torno a 1426 las funciones del Racional sobrepasaban las ocupaciones administrativas de su primera época. Desde ese mismo momento se transformaba en un cargo eminentemente político, que no sólo controlaba la elección del ejecutivo ciudadano sino que además solventaba - sin las habituales reticencias de la oligarquía local- las extraordinarias peticiones económicas que la corona solicitaba al municipio para sufragar sus campañas militares ${ }^{14}$. La trascendencia político-económica del oficio justificaba la creciente intromisión del poder real en la constitución y renovación del gobierno municipal, consolidando el creciente autoritarismo monárquico e iniciando una continuada política de préstamos municipales a la monarquía. La correlación entre fiscalización, finanzas municipales e interés regio por el cargo era completa. Por esta razón el Racional dejaba de ser designado por el ejecutivo ciudadano y era la misma monarquía quien sugería el nombre del titular. De esta forma el Racional se convertía en el hombre del rey dentro de la administración ciudadana haciendo las veces del corregidor castellano según señalaba $E$. Belenguer. Sintomáticamente el período de ejercicio de la titularidad del

${ }_{14}$ Cfr. F. Sevillano Colom, Préstamos de la ciudad de Valencia a los reyes Alfonso $V y$ Juan II (1426-1472), Valencia, 1951, pp. 511-623. Como ha señalado E. Belenguer es evidente la coincidencia entre la introducción de la ceda y la concesión del primer préstamo de Valencia a Alfonso el Magnánimo en 1426. La consolidación de una monarquía cada vez más autoritaria reducía sensiblemente las interminables luchas de bandos que Valencia padecía, y en última instancia terminaba por encumbrar a los linajes ciudadanos que apoyaron a los Trastámara durante el Interregno. 
oficio sobrepasaría de modo arbitrario los limites acotados por el Consell en épocas precedentes ".

Es significativo y sobresaliente el interés del rey por encomendar el cargo a una persona de confianza y por esa misma razón podemos comprender el interés ciudadano como poder autónomo en la época inmediatamente precedente por delimitar con precisión la duración del mismo. Tradicionalmente la explicación ha estado justificada por el contraste entre un "autonomismo feudal» en la fórmula de gobierno pactista de la la casa de Aragón frente al "autoritarismo monárquico» inherente a la foránea casa Trastámara. No obstante es necesario remarcar el papel protagonizado por las oligarquías patricias y el reparto de poderes subsiguiente, así como la continuidad de la lucha por el poder -dialéctica o cruenta- entre linajes y bandos enemistados. Las modificaciones en la estructura municipal y los nueve sistemas electorales utilizados sucesivamente entre 1239 y 1419 para proveer los cargos de gobierno sólo se justificaban por esta beligerancia ${ }^{16}$. El control político del municipio por una facción suponía de facto el control económico y financiero del mismo, puesto que el grueso del presupuesto ciudadano era absorbido por los censales emitidos para sufragar el déficit del erario público, por las ayudas destinadas al avituallamiento urbano, por los salarios estipulados para costear la existencia administrativa del poder local, y por las usuales peticiones monetarias de la corona ${ }^{\prime \prime}$.

Esta circunstancia justificaba idéntica mutación de las fórmulas políticoelectorales previstas para la provisión del resto de magistraturas administrativas, y por tanto se constatan con anterioridad a la injerencia real en el poder municipal protagonizada por Alfonso el Magnánimo. Entre 1356 y 1419,

is Al respecto es sugestiva la tesis de $\mathrm{J}$. $\mathrm{M}^{3}$. CRuselles Gómez, Comportamiento social y actividad profesional entre los notarios de la ciudad de Valencia. Siglo XV. Tesis doctoral inédita. (Valencia, 1991). En especial el capítulo "Los juristas, su autonomía como grupo social y su vinculación a los logros del poder público" pp. 239-254. Respecto al nuevo papel adquirido por el Racional destaca la prolongación cronológica de su ejercicio por los titulares filoregios como Manuel Suau (1435-1455) o Guillem Çaera (14551477).

${ }^{16}$ Cfr. R. Narbona Vizcaíno, Gobierno político y luchas sociales. Patricios y malhechores. Siglos XIV y XV, «Saitabi», 39 (Valencia, 1989) pp. 81-97 como introducción y presentación genérica de mi tesis doctoral: Gobierno politico y luchas sociales. Estrategias de poder del patriciado urbano. La ciudad de Valencia (1353-1418). Tesis doctoral inédita (Valencia, 1989).

17 Los gastos derivados del mantenimiento o de la inversión regular en obras edilicias, infraestructura viaria-hidráulica se sufragaban así mismos y en cualquier caso, a tenor de los ejemplos de Alzira o Castellón, nunca supusieron más que una mínima parte del total del presupuesto municipal. Cfr. C. SÁnCHEZ CUTILlas, La Fábrica vella, dita de Murs i Valls, "VIII Congreso de Historia de la Corona de Aragón», II, Valencia, 1970, pp. 199-200. 
durante una prorrogada fase de alteraciones orgánico-electorales se puede rastrear la escasa estabilidad de las magistraturas.

2. Los Administradors de les imposicions eran dos y tenían como misión administrar y vender las imposicions de la ciudad desde 1351 , a partir de una concesión regia otorgada en 1348, que delegaba en los recaudadoresadministradores locales cierta coparticipación en las tareas previstas para los Administradores diputados por el rey (encargados de recaudar los impuestos reales). Fueron nombrados directamente por los Jurats hasta que en 1374 se instituyó como método de elección el sorteo de redolins en la vigilia de Pentecostés. Los candidatos serían propuestos desde las parroquias según el método usual y de creciente utilización. De las ocho bolas restantes en la elección de los Jurats ciutadans se escogerían cuatro y se leerían los nombres que contuviesen. Finalmente los Jurats adjudicarían a cada una de esas personas un puesto determinado entre cargos de Obrer de murs $i$ valls, Clavari censals y las dos plazas de Administradors de les imposicions. La conveniencia de designar a una u otra de las cuatro personas sorteadas por segunda vez reside en una decisión de la máxima instancia política ciudadana ${ }^{18}$.

3. El Clavari censals era el oficial encargado del pago puntual de los plazos acordados por la venta de deuda pública local. Los gastos ocasionados para sufragar el abastecimiento urbano, los salarios acreditados anualmente, los préstamos al monarca, la misma amortización de la deuda pública, etc, agotaban con extraordinaria rapidez las cantidades líquidas del numerario ciudadano. Las arcas del común necesitaban con urgencia vías de financiación para atender a las inmediatas e imperativas necesidades. Así desde finales de la década de los cincuenta del siglo XIV la institución municipal compraba capitales particulares - moneda al contado- con la promesa de pagar un interés anual hasta su devolución. La fórmula de financiación se regularizaría en 1367 cuando ciertos préstamos realizados por cambistas locales se transformaron definitivamente en censales. Desde 1374 la magistratura era provista en la vigilia de Pentecostés junto a los Administradors de les imposicions según la dinámica anterior, pero desde 1392 su titular es electo en la víspera de Navidad. En esa fecha dejaría de ser sorteado entre los candidatos parroquiales propuestos para ser el Consell y los Jurats quienes nombrasen directamente a la persona que considerasen óptima ${ }^{11}$. Es evidente el control directo que el ejecutivo político ejercía sobre el cargo administrativo. 20).

18 Cfr. AMV, Manuals de Consells A-10 (1351, junio 15) y A-16 (1374, mayo

19) Cfr. Idem, A-16 (1374, mayo 20), A-19 (1390, diciembre 22) y A-20 (1392, diciembre 22). 
4. Los Instadors del quitament constituían un grupo de doce personas que junto a los Jurats aconsejaban al Clavari Censals. Su misión radicaba en anotar puntualmente los gastos realizados por el común para tratar de aligerar la deuda municipal. Cuando el balance anual de cuentas producía superavit los doce instaban, favorecían y regulaban el quitamiento de los capitales comprados (redención o amortización de la totalidad o parte de la deuda). Los Instadors constituían una especie de consejo político con la única finalidad de reducir el montante global de los intereses censales pagados anualmente, devolviendo los capitales particulares vendidos a las arcas públicas. El grupo se renovaba regularmente en Navidad cuando dos de los más antiguos consejeros abandonaban el grupo mediante sorteo y, a la vez, las nominaciones de candidatos desde las parroquias ciudadanas cubrían las vacantes ${ }^{20}$. El azar producía la selección y propiciaba la renovación del cuerpo en base a un amplio consenso ciudadano.

5. El Clavari de la pecúnia comuna era el oficial encargado de pagar los gastos ordinarios con el líquido ingresado de sus rentas fijas, principalmente las imposicions o sisas que gravaban el vino, la carne, el pan, la mercaderia y el tall del drap. Desde principios de siglo la costumbre dejaba en manos de los Jurats la designación directa del magistrado pero desde 1327 quedó establecido que uno entre ellos regiría la administración. Desde 1386 el cargo completamente independizado del ejecutivo se proveía con los ocho candidatos ciudadanos no electos en el sorteo de Jurats: cinco de ellos irían a cubrir las vacantes anuales de la administración entre las que se encontraba el clavario del común. Los redolins no designarían a una persona para cada puesto sino que cada una de ellas sería nombrada como titular de una de estas oficialías según la indicación expresa de los Jurats. En última instancia y desde 1401 la magistratura era provista anualmente por designación directa de los Jurats en la vigilia de Pentecostés ${ }^{21}$. La perpetuación de la relación directa entre el poder político y la hacienda municipal es completa.

6. El Sindic era el oficial encargado de ostentar la representación o procuración de la institución frente a otras instancias de poder. Según el marqués de Cruilles aparece por primera vez como procurador del común en 1346, aunque en 1355 es electo por unanimidad de los Jurats entre los notarios de la ciudad. En 1377 todavía no es un cargo de elección anual y sigue siendo provisto con el albedrío de los Jurats, Justícies y prohombres del Consell. R. Ferrero señalaba que la duración de su ejercicio en principio fue de carácter

20 Por ejemplo, cfr. Idem, A-25 (1413, diciembre 20).

${ }^{21}$ Cfr. Idem A-2 (1327, mayo 31), A-18 (1386, junio 9) A-22 (1401, mayo 24). 
perpétuo, pero en realidad la persona designada ostentaba la representación del Consell hasta que éste ordenaba lo contrario. Desde 1396 es electo a partir de la nominación de candidatos realizada por los prohombres siendo sometida a la votación de todo el Consell. Finalmente en 1414 se estipulaba que la titularidad del oficio debería cambiar cada dos años, acotación coordinada con la habilitación anual de un oficial subordinado: el Sotsindic. Éste fue electo desde 1406 a votación por todo el Consell, hasta que desde 1414 los candidatos fueron nominados por el Racional, el Escrivà y el Síndic".

7. Frente al carácter administrativo de la representación que el municipio otorgaba al Síndic existía otro tipo de procuración: la embajada política conferida por el gobierno ciudadano a ciertos agentes especiales. Las mensajerías enviadas al monarca o a otras instituciones (incluso las sindicaturas a Cortes) daban entidad política al titular electo como procurador o representante del municipio bajo todo tipo de reservas y condiciones. El delegado raramente poseía amplios poderes sino que generalmente se hallaba sujeto a las decisiones que adoptara el Consell. En este sentido, el municipio designaba entre sus prohombres a algunos para desempeñar ciertas tareas de mediación, procuración o representación tanto para consultar como para solventar los problemas. Es decir, el cargo de Missatger o Síndic era elegible sólo para la realización de una tarea determinada no constituyendo un puesto fijo o un oficio propiamente dicho. Más que una magistratura constituye una misión encomendada y por tanto se proveía a partir de la propuesta de posibles candidatos: los Jurats nominarían a cierto número de personas que eran votadas por el conjunto del Consell, otorgándose la misión por mayoría. El método no era exclusivo porque desde 1396 los Jurats designaron una comisión de prohombres encargados de nominar a los candidatos que habrían de estar sujetos a votación por todo el Consell ${ }^{23}$.

En conclusión, podemos subrayar que en la configuración electoral de las magistraturas se observa una auténtica mediatización del poder político en la provisión de los cargos administrativos del municipio, que cobra especial relevancia en el nombramiento de magistrados. La capacidad de proponer individuos concretos estaba monopolizada por los Jurats aunque ésta podía participar de un sorteo de candidatos propuestos por el amplio consenso del Consell o de las parroquias ciudadanas. En éstas se concentraban las más relevantes prerrogativas políticas del municipio (capacidad de nominación-

22 Cfr. Idem, A-12 (1355, junio 12), A-17 (1377, agosto 14), A-21 (1396, junio 23), A-22 (1406 junio 18 y 1414 marzo 14). Y también M. de CRUYLLES, Los gremios de Valencia. Memoria sobre su origen, vicisitudes o organización, Valencia, 1883, p. 54.

${ }^{23}$ Cfr. Idem, A-19 (1389, marzo 22) y A-21 (1396, julio 4). 
selección de aspirantes que optaban al ejercicio del poder local) con anterioridad a la mediatización de las funciones y de las magistraturas derivada de la injerencia monárquica en la dirección política del municipio.

\section{LA FINANCIACIÓN DEL ABASTECIMIENTO FRUMENTARIO}

Esta singular relación entre poder y administración municipal también se reproduce en el abastecimiento frumentario de Valencia medieval. El reino era deficitario en trigo y por esta razón la capital tuvo que confeccionar una precisa política económica encaminada a solventar la acuciante problemática, para lo cual emplearía un amplio formulario de posibilidades institucionales que abarcaron desde las gratificaciones económicas hasta los procedimientos jurídicos, y desde el empleo coercitivo de la fuerza militar hasta el corso. Su perentoria conjugación tenía como objetivo indispensable cumplimentar el regular abastecimiento alimenticio de la urbe en momentos de dificultad. Así las naves valencianas gozaron de licencias de los Jurats para apresar embarcaciones cargadas de grano. En ocasiones el mismo Consell realizó algunos encargos directos a ciertos mercaderes especializados en el tráfico frumentario, $\mathrm{e}$ incluso envió agentes - missatgers- a los centros de producción para contratar in situ el imprescindible avituallamiento ". Aún más, la capital impondría sus necesidades y criterios sobre el resto del reino esgrimiendo los furs y privilegis de forma prepotente. Desde los mismos tiempos de la conquista había quedado consagrado el dominio efectivo de Valencia ciudad sobre todos los alimentos producidos incluso más allá de la extensa área rural de su término jurisdiccional, aunque cada vez que la capital intentaba usufructuar este derecho topaba con la oposición sistemática y la abierta rebeldía de las poblaciones afectadas (las pequeñas y medianas villas) ${ }^{25}$.

La sucesión casi ininterrumpida de crisis frumentarias a lo largo del primer

${ }^{24}$ Algunos ejemplos relevantes nos los proporcionan el linaje Marrades. Pere desempenoó varias misiones especiales encomendadas por el Consell: en 1369 recibió la orden para que aseguràs e fes venir (a Valencia) el cargamento de la nave de Pere Blau de Barcelona que había sido comprado con antelación por el municipio, y en 1375 marchó a Sevilla, Cádiz y otros lugares de Castilla para anudar relaciones político-comercales que propiciaran el envío de varias cargas de grano a los silos valencianos; en 1385 Jaume Marrades y micer Domingo Mascó, doctor en leys, abogado pensionado de Valencia, se entrevistaban con Alvar Garcia Albornoz para que fuera revocada la prohibición que impedía exportar trigo castellano. Cfr. AMV, Manuals d'albarans de claveria comuna I-2 (1369, abril 4) I-8 (1375 febrero 19, marzo 30 y junio 6) e I-14 (1385 febrero 8 y mayo 15 ).

25 Respecto al abastecimiento frumentario valenciano cfr. los trabajos de A. RUBIO, 
tercio del siglo XIV incrementó las dificultades de avituallamiento, fomentando y acelerando la configuración de cierto dirigismo en la política económica de las municipalidades. Solventar el problema de las subsistencias era una necesidad perentoria por el importante contingente poblacional que comenzaba a albergar Valencia tras sus murallas. Según A. Rubio el ciclo malas cosechas-carestías-altos precios cerealícolas aquejaron a Valencia con una cadencia espasmódica durante toda la centuria $(1310-1314,1324$ $1329,1333,1340,1347-1348,1350,1360-1365,1367,1374-1375$, 1384-1395, etc). Desabastecimiento que en el último tercio del siglo XIV contrastaba todavía más con una demografía ininterrumpidamente alcista. De los casi cinco mil fuegos de mediados del Trescientos (1355) se alcanzaron los ocho mil a principios del Cuatrocientos (1415). Las hambres y las pandemias convertían a Valencia en un auténtico polo de atracción de inmigrantes en épocas de penuria, debido a que los imperativos políticos imponían la distribución de grano tratando de evitar a toda costa desórdenes y tumultos. La solución de las subsistencias también constituía un problema de supervivencia para los mismos magistrados locales. En estas circunstancias los Jurats intervinieron y organizaron un comercio de productos agrarios. Evitar que el habitual déficit frumentario (desorbitado coyunturalmente por las crisis) se transformara en catástrofe suponía importar por vía marítima grandes cantidades de cereal de forma fluida y regular. El municipio lograría consolidar eficaces mecanismos económicos para garantizar la subsistencia material de sus habitantes, conectando con los circuitos y redes de distribución comercial mediterráneas, aún a costa de que esa participación institucional construyese un mercado desnaturalizado, debido al empleo generalizado de métodos políticos para fomentar la importación (subvenciones, gratificaciones y préstamos) y la distribución interior (precios artificiales, silos municipales, ordenanzas restrictivas).

Este intervencionismo buscaba a toda costa la regulación del mercado y sobre todo evitar drásticas alteraciones de los precios ante la deficitaria y precaria producción local. Según P. Iradiel la importación de granos vía

Ideologia burgesa i progrés material a la València del Tescents, "L'Espill», 9 (Valencia, 1981), p. 35; Historia del pueblo valenciano, Valencia, 1989-1990, vol. I, capítulo 15; Epistolari de la València medieval, Valencia, 1985, pp. 29-30; Crisis agrarias y carestias en las primeras décadas del siglo XIV. El caso de Valencia, "Saitabi», 37 (Valencia, 1987), pp. 131-148; A propósito del "mal any primer»: dificultades cerealisticas en la Corona de aragón en los años treinta del siglo XIV, «Estudios dedicados a Juan Peset Aleixandre», Valencia, 1982, p. 480. En colaboración con M. RODRIGO, El problema frumentari a València i la crisi de la Unió (1340-1348), «Homenatge a Sebastià Garcia Martínez», Valencia, 1989, pp. 94-100. Todos los cuales hipervaloran la precariedad del abastecimiento ciudadano subrayando el temor al hambre en épocas de penuria. 
maritíma mediante métodos y programas institucionales estaría en relación con las previsiones municipales. La compensación del presunto y calculado déficit se realizaría mediante el «recurso intervencionista» hacia el habitual, agil, y desarrollado mercado frumentario mediterráneo. El éxito de los complejos sistemas financieros arbitrados para solucionar el abastecimiento daría como resultado en última instancia la escasa incidencia de las crisis trigueras, la completa estabilidad de los precios, y la inexistencia de conflictividad social, que en las sociedades preindustriales siempre encontraba su caldo de cultivo en dinámicas de escasez y precios inaccesibles ${ }^{26}$.

Los instrumentos económicos del dirigismo municipal para el fomento de la actividad importadora fueron fundamentalmente tres, y remontabán su existencia a las primeras carestías del Trescientos si bien sólo desde mediados de siglo comenzó a regularizarse su práctica ${ }^{27}$. El primero consistía en la concesión de préstamos por la municipalidad a determinados mercaderes sin percibir interés alguno por los capitales encomendados. Una segunda posibilidad contemplaba la garantía un precio de venta asegurado en el almudín local a todo el cereal que llegara al puerto, de modo que la actividad importadora podía prever unos beneficios de antemano. El tercer método se caracterizaba por la concesión de ajudes institucionales (subvención por cahiz de grano vendido en el almudín) a algunos proyectos privados destinados a sufragar las regulares necesidades alimenticias.

Con esta polivante estructura las necesidades frumentarias quedaban salvaguardadas y se construía un marco económico e institucional propiciatorio del avituallamiento. La insatisfacción de la demanda en base a la parca producción propia obligó desde fecha temprana a los dirigentes locales a recurrir con habilidad hacia el mercado triguero mediterráneo hasta el punto de consolidar un eficiente circuito mercantil. El precio de la medida de grano osciló con escaso margen en Valencia bajomedieval porque el municipio basculaba la posible penuria hacia las medidas político-económicas arbitradas. El aumento de las subvenciones o ayudas equilibraba de nuevo la situación fomentando el abastecimiento con carácter inmediato. Cuando se preveían años de escasez les ajudes aumentaban en cuantía (oscilaron entre dos y seis sueldos por cahiz entre 1381 y 1385) mientras los préstamos

${ }^{26}$ Cfr. P. IRADIEL, Producción, autoconsumo y mercado de alimentos en el País Valenciano (siglos XIII-XV. Ponencia presentada al «Primer Coloquio de Historia de la Alimentación de la Corona de Aragón (Edad Media), celebrado en Lérida en noviembre de 1990. En prensa.

27 Sobre los sistemas de abastecimiento de Valencia cfr. los artículos de H. Rausell, M. Llop, D. Guillot, y E. Belenguer en el número monográfico de la revista «Estudis», 2 (Valencia, 1974). También A. CUEVES, Abastecimientos de la ciudad de Valencia durante la Edad Media, "Saitabi», 13 (Valencia, 1963), pp. 143-148. 
institucionales se incrementaban. Sin embargo, los intereses altruistas de la cosa pública se conjugaban con los de la clase política que la gobernaba hasta el extremo de que estos mecanismos serían manipulados en provecho de la oligarquía patricia. La importación de cereales constituyó una singular fuente de ingresos en el diversificado mundo de los negocios. La coincidencia de intereses entre la urbe, su clase dirigente y los mercaderes lo posibilitaba. Incluso ante las problemáticas coyunturas de finales del Trescientos el patriciado logró superar el problema con escasas repercusiones sociales, los habitantes cubrieron sus necesidades de subsistencia mediante los precios intervenidos, y los mercaderes obtuvieron un beneficio inmejorable sin trasladar el costo a los consumidores. Del mismo modo, la oligarquía local que había confeccionado las pautas de abastecimiento, participaba directamente en el negocio de importación de vituallas, obteniendo sustanciales beneficios con la subvención pública y beneficiándose de los precios arbitrados. Buen ejemplo al respecto nos proporcionan dos relevantes linajes ciudadanos - los Marrades y los Suau según los cuadros anexos- que se perpetuaban en la regencia de las magistraturas municipales a lo largo de todo el Trescientos. Por una parte la demanda habitual garantizaba un buen precio de venta mientras que por otro lado se percibía una subvención institucional, que dependía de la calidad del producto importado, de la distancia de la zona exportadora, del cumplimiento del plazo de entrega acordado y de las prioridades de su aprovechamiento.

La cronología de las importaciones realizadas por los Marrades es indicativa porque carece de antecedentes o de continuidad posterior, y porque la década 1370-1380 coincide con una fuerte crisis de subsistencia. La parquedad de la producción local entre 1374-1375 obligó a incrementar la importación de grano por el sistema de ayudas para asegurarse el abastecimiento y no alterar los precios. La coyuntura sería utilizada para comprar cereal preferentemente en Sicilia siendo transportado directamente al almudín de Valencia en naves de la ciudad de Barcelona. El total importado a los silos ciudadanos asciende a 5.653 cafices, 9 barcelles 2 almudes de trigo, es decir más de 791 toneladas de grano ${ }^{28}$. La máxima afluencia está concentrada entre 1372 y 1378: en seis años importaron la práctica totalidad de la cantidad citada (708.520 litros) coincidiendo con un período de necesidad y elevadas subvenciones. Al mismo tiempo estas ayudas se añaden a los beneficios personales derivados de la venta del cereal en el almudín acorde con un precio estipulado de antemano. Es de remarcar que en los diecisiete años y diez viajes realizados los Marrades

${ }^{28}$ La cifra supone aproximadamente 791.435 litros de cereal según las equivalencias: 1 cahiz $=12$ barcelles, 12 barcelles $=1$ quartera, 1 barcella $=4$ almudes, 1 quartera $=70$ litros. 
obtuvieron en concepto de subvención municipal 23.422 sueldos 11 dineros. A todas luces esta actividad no era una de las empresas de riesgo que caracterizarían al arte de la mercadería a finales del Trescientos. Sin embargo, los beneficios eran sustanciosos puesto que los Marrades sólo importaron cereal coincidiendo con las cotas más altas de las subvenciones, con su predominio político en la municipalidad, con circunstancias de penuria frumentaria local y con la construcción de una red de distribución mercantil coherente y regular. Además del lucro extra, subvencionado por la institución de gobierno que monopolizaban, tenían asegurada la venta de grano a precio fijo (estipulado por el Consell) en el almudín ".

Importación de trigo mediante "ajudes" por el linaje Marrades (1372-1389)

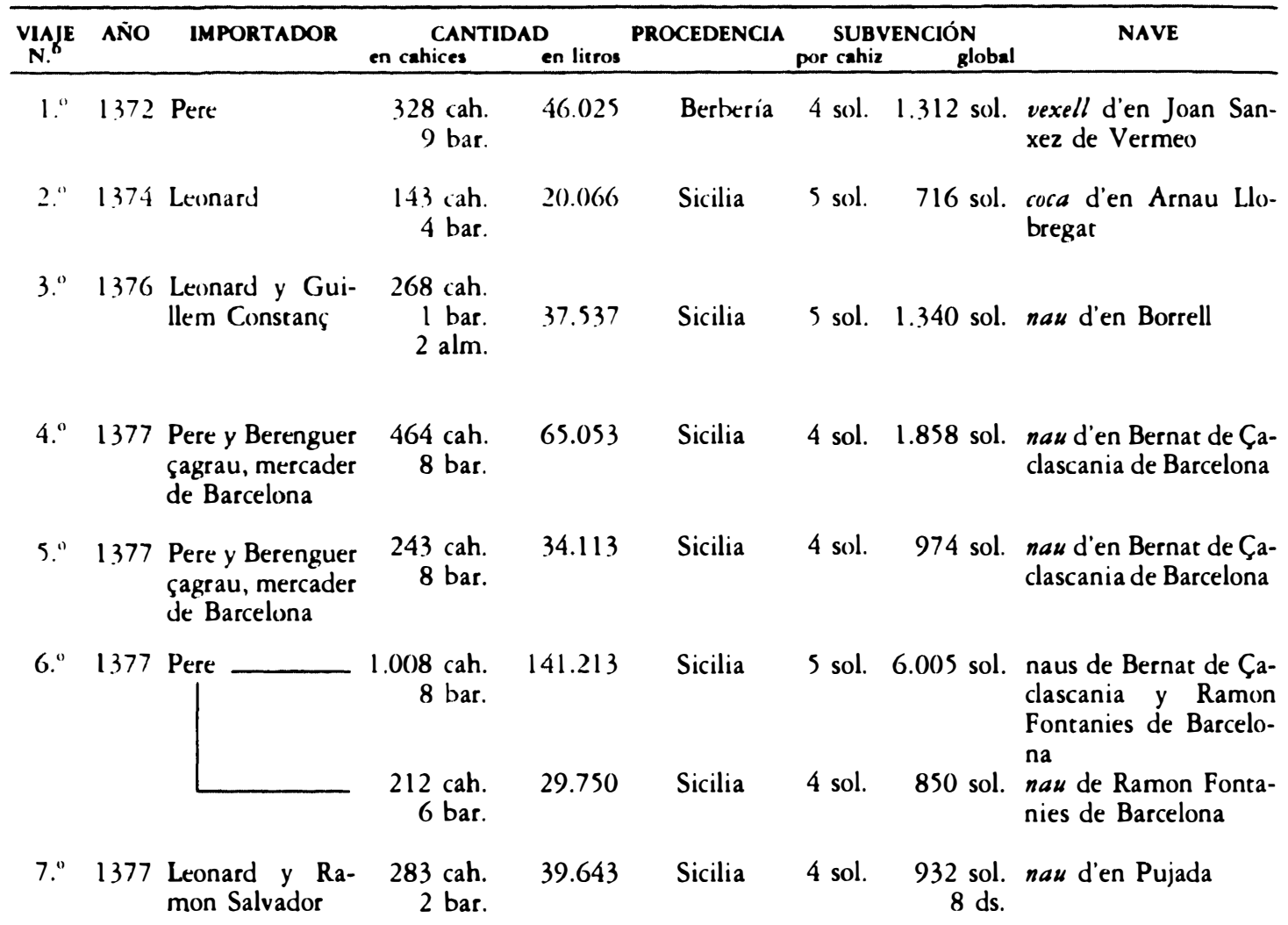

20. Es difícil conocer con exactitud el montante global derivado de la venta en el almudín por las variaciones de precios. No obstante, a título aproximativo y referencial es de consignar que en 1377 el cahiz de trigo era vendido a cincuenta sueldos (poco más de un sueldo el almud). Cfr. AMV, Manuals d'albarans de claveria comuna I-9 (1377, febrero, 28). 


\begin{tabular}{|c|c|c|c|c|c|c|c|c|}
\hline$\underset{\text { N. }}{\text { VIAfE }}$ & AÑO & IMPORTADOR & $\begin{array}{l}\text { CANT } \\
\text { en cahices }\end{array}$ & $\begin{array}{l}\text { AD } \\
\text { en lieros }\end{array}$ & PROCEDENCIA & $\begin{array}{r}\text { SLiB } \\
\text { por cahiz }\end{array}$ & $\begin{array}{l}\text { VENCION } \\
\text { global }\end{array}$ & NAVE \\
\hline 8." & 1378 & $\begin{array}{l}\text { Pere y Pepe Car- } \\
\text { bo }\end{array}$ & 992 cah. & 138.88() & Sicilia & $3 \mathrm{sol}$. & $2.976 \mathrm{sol}$. & $\begin{array}{l}\text { nau den Ramon Fon- } \\
\text { tanies }\end{array}$ \\
\hline 9." & 1378 & Pere & $1.116 \mathrm{cah}$. & 156.240 & Sicilia & $3 \mathrm{sol}$. & $3.498 \mathrm{sol}$. & nau de Pere Carbo \\
\hline 10." & 1389 & $\begin{array}{l}\text { Jaume y Mateu } \\
\text { Vidal }\end{array}$ & $\begin{array}{l}592 \text { cah. } \\
3 \text { bar. }\end{array}$ & 82.915 & Sicilia & 5 sol. & $\begin{array}{r}2.961 \mathrm{sol} \\
3 \mathrm{ds}\end{array}$ & $\begin{array}{l}\text { nau d'en Salvador An- } \\
\text { gelats de Barcelona }\end{array}$ \\
\hline
\end{tabular}

Importación de trigo mediante el sistema de "ajudes" por el linaje Suau (1381-1388)

\begin{tabular}{|c|c|c|c|c|c|c|c|c|}
\hline \multirow{2}{*}{ 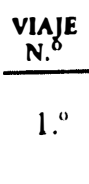 } & \multirow{2}{*}{$\frac{\text { AÑo }}{1381}$} & \multirow{2}{*}{$\begin{array}{l}\text { IMPORTADOR } \\
\text { Pere Suau }\end{array}$} & \multirow{2}{*}{$\frac{\begin{array}{c}\text { CANTID } \\
\text { en cahices }\end{array}}{265 \text { cah. }}$} & \multirow{2}{*}{$\begin{array}{l}\text { AD } \\
\text { en litros } \\
37.100\end{array}$} & \multirow{2}{*}{$\begin{array}{c}\text { PROCEDENCIA } \\
\text { Berbería }\end{array}$} & \multicolumn{2}{|c|}{$\begin{array}{c}\text { SUBVENCIÓN } \\
\text { por cahiz global }\end{array}$} & NAVE \\
\hline & & & & & & $\begin{array}{l}2 \text { sol. } \\
6 \text { ds. }\end{array}$ & $\begin{array}{l}662 \text { sol. } \\
6 \text { ds. }\end{array}$ & $\begin{array}{l}\text { coca de Berenguer } \\
\text { Narbó }\end{array}$ \\
\hline 2." & 1381 & Pere Suau & $1.145 \mathrm{cah}$. & 160.300 & $\begin{array}{l}\text { Berberia } \\
\text { (Oran) }\end{array}$ & $3 \mathrm{soll}$ & $3.235 \mathrm{sol}$ & nau de Ramon Ferrer \\
\hline $3 .{ }^{\circ}$ & 1381 & Pere Suau & 72 cah. & 10.080 & Berbería & $3 \mathrm{sol}$ & $216 \mathrm{sol}$ & $\begin{array}{l}\text { barcha de Berenguer } \\
\text { Esparaguera }\end{array}$ \\
\hline $4^{\circ}$ & 1381 & Pere Suau & $\begin{array}{l}164 \text { cah. } \\
4 \text { bar. }\end{array}$ & 22.960 & $\begin{array}{l}\text { Berbería } \\
\text { (Orán) }\end{array}$ & 3 sol. & 493 sol. & Idem \\
\hline 5." & 1382 & Pere Suau & 812 cah. & 113.680 & $\begin{array}{l}\text { Berbería } \\
\quad \text { (Orán) }\end{array}$ & 3 sol. & 2.437 sol. & $\begin{array}{l}\text { barcha de Miguel } \\
\text { d'Arbidia (sent Sebas- } \\
\text { tià) y la de Joan de Co- } \\
\text { runya (Galicia) }\end{array}$ \\
\hline 6." & 1383 & $\begin{array}{l}\text { Pere Suau y Gui- } \\
\text { llem Gostanç }\end{array}$ & $1.600 \mathrm{cah}$ & 224.000 & Flandes & $6 \mathrm{sol}$. & 9.600 sol. & \\
\hline $7.0^{\circ}$ & 1385 & Pere Suau & 345 cah. & 48.300 & Sicilia & 5 sol. & 1.726 sol. & $\begin{array}{l}\text { nau de Pino Campo de } \\
\text { Mesina }\end{array}$ \\
\hline $8 .^{\circ}$ & 1385 & Pere Suau & $\begin{array}{l}68 \text { cah. } \\
9 \text { bar }\end{array}$ & 9.520 & Aragón & $4 \mathrm{sol}$. & $275 \mathrm{sol}$ & \\
\hline $9 .{ }^{\circ}$ & 1385 & Pere Suau & 224 cah. & 31.360 & Berbería & $4 \mathrm{sol}$. & 897 sol. & coca de Pere Montalar \\
\hline $10 .^{\circ}$ & 1387 & Pere Suau & 702 cah. & 98.280 & Berbería & 4 sol. & 3.004 sol. & nau de Guillem Vidal \\
\hline $11 .{ }^{\circ}$ & 1387 & Pere Suau & $1.459 \mathrm{cah}$. & 204.260 & Berbería & $4 \mathrm{sol}$. & 5.827 sol. & $\begin{array}{l}\text { barcha de Pero Sanxez } \\
\text { y nau de Guillem Vi- } \\
\text { dal }\end{array}$ \\
\hline $12 .^{\circ}$ & 1387 & Pere Suau & $2.210 \mathrm{cah}$. & 309.400 & Berbería & - & 1.105 sol. & \\
\hline $13 .^{\circ}$ & 1388 & Pere Suau & $\begin{array}{r}832 \text { cah. } \\
4 \text { bar }\end{array}$ & 116.480 & Berbería & $\begin{array}{l}4 \mathrm{sol} . \\
6 \mathrm{ds} .\end{array}$ & 3.725 sol. & $\begin{array}{l}\text { coca de Ferrer Cuiter y } \\
\text { nau de Guillem Vidal }\end{array}$ \\
\hline
\end{tabular}




\begin{tabular}{|ll|}
\hline SíMBOLOS: & \\
cah. & cahices \\
bar. & barcelles \\
alm. & almudes \\
sol. & sueldos \\
ds. & dineros \\
\hline
\end{tabular}

Del mismo modo, siguiendo la tónica descrita entre 1381 y 1388 los Suau financiaron trece cargamentos. En siete años consecutivos importaron 9.899 cahices de trigo ( 1.385 toneladas) procedente de Berbería que les reportaron una subvención total de 33.202 sueldos. Pero los Suau emplearon otros medios institucionales para abastecer de grano Valencia. En 1385 Joan Suau menor y Bertomeu de Tena percibieron 31.571 sueldos en tres plazos consecutivos de las arcas del común ciudadano por la importación desde Flandes de 442 cahices 6 barcelles de forment (61.950 litros), los cuales llegarían a Valencia en la nave de Joan Ivanyes de Bermeo. En esta ocasión Joan Suau y Bertomeu de Tena se habían concordado de antemano con el municipio estipulando un precio de venta (entre 50 y 52 sueldos por cahiz) ${ }^{30}$. El último cauce utilizado fue tomar fondos prestados de las arcas municipales: Pere Suau major y Ramon Salvador percibieron 22.000 sueldos ". Desconocemos a cuanto ascendió el interés de este préstamo pero teniendo el precio asegurado en el almudín, las facilidades financieras habituales, y ostentando relevantes puestos políticos en la municipalidad-que permitían controlar los cauces de abastecimiento cerealícola- podemos deducir un riesgo mercantil escaso o inexistente.

\section{LA DEUDA PÚBLICA: LOS CENSALES MUNICIPALES}

La proyección político-económica de los linajes ciudadanos sobre el municipio también se detecta en la compra-venta de deuda pública hasta el punto de presentar un ininterrumpido intercambio entre finanzas públicas y privadas. La inversión de capitales particulares en estos censales se fundamentaba en la obtención de una renta anual, prorrogable indefinidamente hasta la devolución del capital a disposición de la administración, con el fin de sufragar las

30 Cfr. AMV, Manuals d'albarans de claveria censals I-14 (1385, mayo 20).

${ }^{31}$ Cfr. AMV, Manuals d'albarans de claveria censals I-14 (1385, mayo 20). 
imperativas necesidades de numerario líquido que permitieran financiar la política ciudadana. El objetivo preferencial de la financiación censal fue el abastecimiento, los préstamos y donaciones al rey, los gastos derivados de la administración, el armamento de naves para combatir piratas... o todo tipo de situaciones que hacían imprescindible la rápida disposición de importantes cantidades de numerario.

El sistema de cargamientos de censales se generalizó a mediados del siglo XIV en los países de la Corona de Aragón. Mientras Barcelona comenzó a aplicarlo como fórmula de financiación municipal entre 1326-1340, Valencia esperaría hasta 1355-1360, a partir de lo cual comenzaría a regularse la práctica crediticia legislativamente y a expandirse por toda la geografía de las municipalidades bajomedievales, hasta el extremo de convertirse en el eje básico en torno al cual gravitaba el movimiento de dinero ${ }^{32}$. A la larga el desorbitado empleo del mecanismo financiero dió pie un proceso de acumulación de deuda casi irreversible. La imposibilidad de devolver los capitales en base a los recursos ordinarios generaba en última instancia un círculo vicioso que condenaba a las villas y ciudades a emitir nuevos censales para sufragar los intereses adeudados con los primeros. La distorsión del fenómeno fue señalado por E. Belenguer para la época de Fernando el Católico aunque resulta significativa al respecto la fecha de creación de la institución de los Instadors del quitament a comienzos del siglo XV, precisamente cuando el pago de pensiones superó las veinte mil libras anuales iniciando una incontenible tendencia alcista ${ }^{33}$.

Para atraer los capitales privados el municipio arbitraba una renta o interés anual por el préstamo, cuya cuantía osciló entre el 8'33\% y el 7'69\% en la cronología estudiada (1367-1419) si bien se constata su sentido tenden-

12 Cfr. Arcadio García SAnZ, El censal, «BSCC», 37 (Castellón, 1961), pp. 285-305; Vicent OlaSo CENDRA, L'endeudament censal a la vila de Gandia durant la Baixa Edat Mitjana, "Ullal. Revista d'Història i Cultura», 11 (La Safor, primavera 1987), pp. 51-64; e Yván RousTiT, La consolidation de la dette publique à Barcelona au milieu du XIV siècle, "Estudios de Historia Moderna» (dirigidos por J. Vicens Vives), IV (Barcelona, 1954), pp. 13-156.

${ }^{33}$ El primer censal vendido por la ciudad de Valencia data de 1355 cuando las apremiantes necesidades de numerario se justificaban por los preparativos bélicos derivados de la inminente amenaza castellana, y de la subsiguiente construcción y fortificación del nuevo recinto amurallado (la autofinanciada institución de Murs $i$ Valls no se fundaría hasta 1358). Por otro lado las primeras noticias sobre los Instadors del quitament datan de 1413 y 1416 , fechas en que se estipularon los capítulos pertinentes para posibilitar la amortización de los capitales. Es más desde 1399 el Consell obligó a redimir todos los censales cargados en beneficio de extranjeros y personas no domiciliadas en la capital, prohibiéndoseles en adelante la compra de deuda municipal. Cfr. AMV, Manuals de Consells A-21 (1399, julio 9), A-25 (1413, diciembre 13) y A-26 (1416, abril 3). 
cialmente a la baja conforme avanzaba el período (6,66\% a mediados del $\mathrm{XV})^{34}$. Todos los indicios apuntan a pensar que la tasa de interés dependía directamente de las necesidades de dinero líquido impuestas por la coyuntura ciudadana, aunque una media aritmética calculada nos suministraría un ocho por ciento aproximadamente como baremo intermedio para finales del Trescientos. No obstante, a pesar del predominio de las rentas municipales que otorgaban mil sueldos anuales por trece mil de capital prestado (7'99\%) o por doce mil sueldos $\left(8^{\prime} 33 \%\right)$, también existía simultáneamente otro interés más elevado que otorgaba excepcionalmente la misma renta anual por un capital de once mil sueldos ( $9 \%$ ).

La heterogeneidad social que participaba en el concurso inversor abarcaba desde de la población mercantil y nobiliaria hasta los estratos más acomodados de la menestralía. Su extremada difusión social convirtió a los censales emitidos por instituciones en un bien de cambio y en una fuente de singular relevancia para consolidar y transmitir patrimonios ". Sin embargo, lo cierto es que los más prestigiosos linajes patricios que regentaban asiduamente las más relevantes magistraturas constituyeron los agentes sociales que con mayor interés compraban la deuda pública.

Tímidamente al principio, con cierta regularidad después y con auténtica vocación a principios del siglo XV los Suau financiaron con este método la política ciudadana cuando ellos mismos regentaban los puestos de gobierno. Al mismo tiempo también percibieron rentas censales emitidas por la Generalitat valenciana ". La garantía de las inversiones encontraba todas las seguridades en el patrimonio público. Entre 1370 y 1419 percibieron a lo largo de 335 pagos aplazados 129.880 sueldos en concepto de intereses exclusivamente municipales, es decir al menos 3.247 sueldos anuales. De la representación gráfica de todos estos datos se puede deducir una rápida escalada en la percepción de

44 Conocemos el interés de los censales emitidos cuando se consigna el quitamiento de la renta anual aplazada mediante el reintegro del capital desde arcas del común. La salida de numerario era contabilizada como una partida más de la administración financiera y contable en los Manuals d'albarans de claveria comuna.

"Buen ejemplo de las inversiones crediticias y rentistas del patriciado (hasta el $84 \%$ del total) se puede percibir en patrimonios concretos. Cfr. Pau VICIANO, L'estratègia rendista del patriciat valencià: el censal i la terra en les inversions d'un mercader del segle XV, "Afers", 11-12 (València, 1991), pp. 127-136.

${ }^{36}$ Los censales comprados a la Generalitat entre 1404 y 1412 comprendían un interés anual entre el $7^{\prime} 14 \%$ y el $7^{\prime} 60 \%$ coincidiendo también con la regencia de cargos administrativos en la institución. Cfr. M* Rosa MUÑOZ POMER, Orígenes de la Generalidad valenciana, Valencia, 1987, pp. 324, 328 y 330. En los datos cuantificados referidos al municipio faltan las informaciónes de diez años, que figuran en blanco en las representaciones gráficas. 
rentas. El crecimiento de 1370-1382 adquiere caracteres explosivos desde 1396 tras la coronación del rey Martín y el reinicio de campañas mediterráneas. En el período del Interregno (1410-1412) lograron las máximas cotas coincidiendo con el apoyo que la ciudad brindó a la candidatura de Jaime de Urgel. El triunfo y coronación de Fernando de Antequera conllevó la reducción a la mitad de los intereses percibidos, que sólo volverían a recuperarse en 1416 con la llegada al trono de Alfonso $\mathrm{V}$ y el nuevo empuje en la proyección bélica exterior.

Por su parte entre 1367 y 1419 el linaje Marrades con 162 pagos aplazados percibió un total de 86.123 sueldos, es decir una media de 2.050

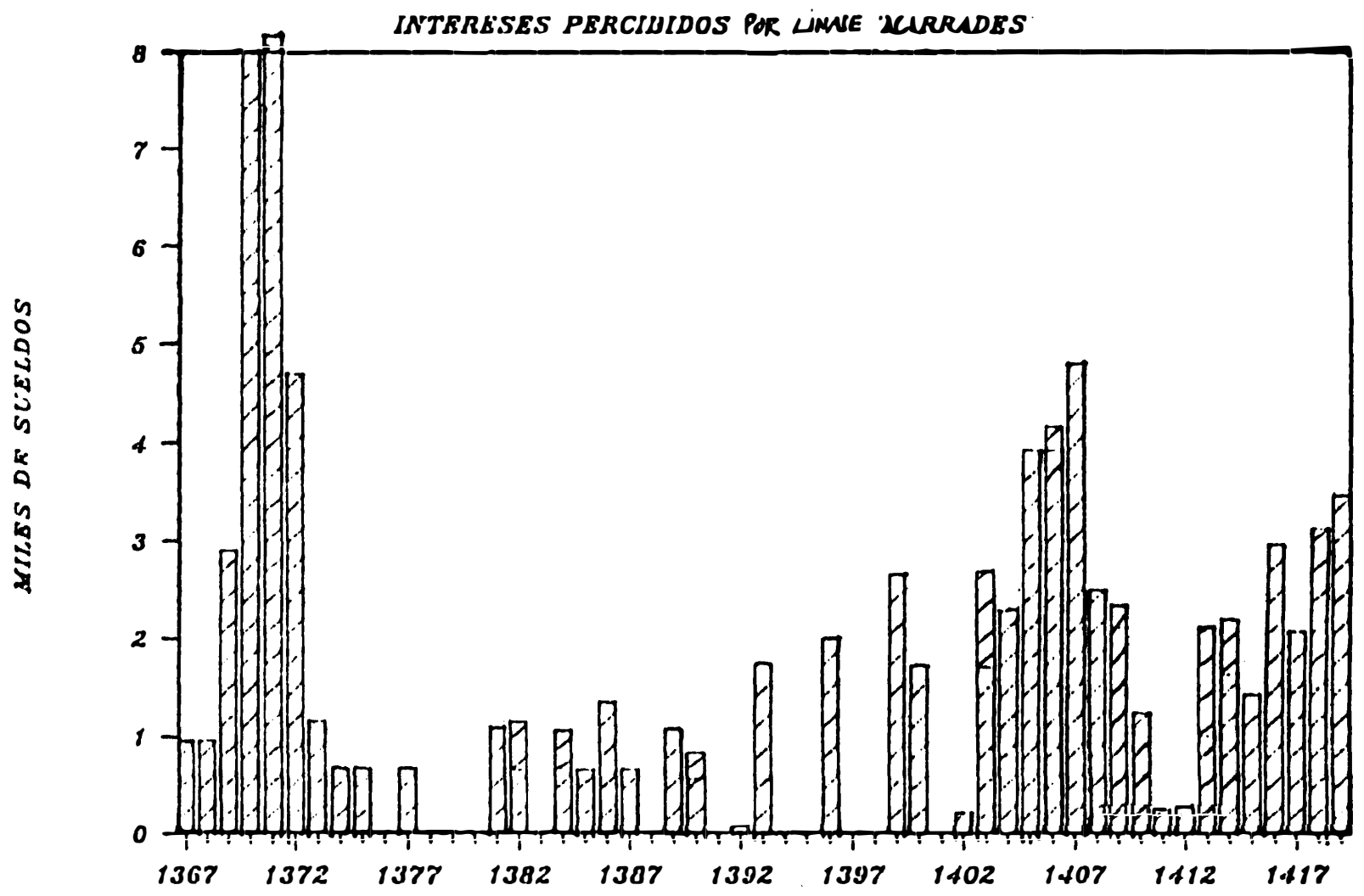




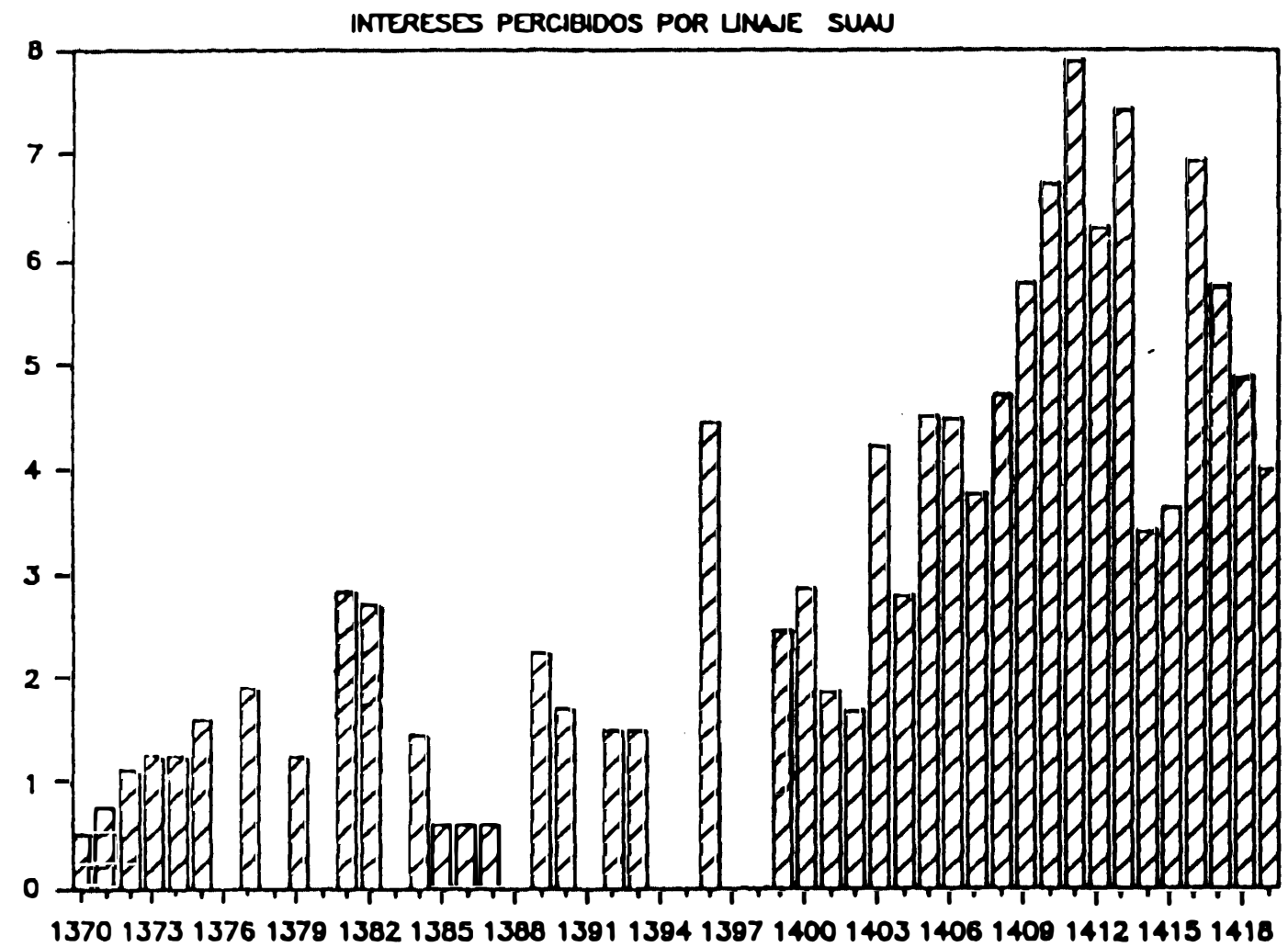

sueldos anuales de renta. Los Marrades remontan este tipo de inversión hasta 1360 aunque el despegue fue increíblemente rápido, alcanzando cotas altísimas en 1369 (casi dos mil sueldos anuales), 1370 y 1371 (casi 6.800 sueldos) coincidiendo con la máxima presencia política del linaje en el gobierno ciudadano. El decrecimiento de 1381-1387 concuerda con el nombramiento de Pere Marrades como Baile General del reino primero y como tesorero real después. No obstante, se percibe cierta continuidad cronológica y regularidad en la cuantía de las rentas hasta que desde 1403 de nuevo se disparan. Los Marrades como ciudadanos se ganaron la confianza de Pedro IV mediante el ejercicio de importantes cargos en la administración local y regia, pasando a integrarse en consejo de gobierno de Juan I, a lo largo de cuyo reinado alcanzarían la cima del prestigio socio-económico. El intento de depuración de los consejeros de Juan I por el consejo de regencia los apartaría momentaneamente del poder. En 1402 ya con Martín el Humano poseían el estatuto de caballeros. Durante el Interregno desaparicieron de la órbita municipal y su nivel de rentas se redujo ostensiblemente, hasta que tras el Compromiso de Caspe fueron amnistiados y 
rehabilitados los antiguos consejeros de Juan I. De nuevo con Alfonso V los Marrades volverían a ejercer puestos de gobierno pero ahora como caballeros.

\section{LA FISCALIDAD MUNICIPAL: EL ARRENDAMIENTO DE IMPUESTOS}

La temprana cesión real de los mecanismos financieros y fiscales necesarios para su autogobierno fue casi coetánea a la institución de los primeros municipios. En principio, la fiscalidad del gobierno ciudadano debía de cumplimentar sus gastos administrativos aunque la distorsión respecto a sus ingresos también fue temprana. El arrendamiento de las sisas a terceros constituiría la técnica de bombeo utilizada usualmente para inyectar los ingresos anuales a las arcas del común, cuyos fondos al menos desde 1399 se dedicaban a quitar las cargas censales contraídas con particulares. El presupuesto municipal aparece ya entonces completamente configurado en base a la estrategia de emisión de deuda pública ${ }^{37}$.

La confusión entre las actividades públicas del patriciado y sus negocios privados también se desprende de la regularidad del arrendamiento de estos impuestos. De nuevo la utilización de medios políticos sobresale por la construcción de fortunas privadas desde la prepotencia en el gobierno municipal. Los Marrades y los Suau lograron adjudicarse habitualmente la recaudación de impuestos municipales participando en las subastas públicas organizadas anualmente por el Consell. La percepción de las sisas que gravaban el consumo y el tráfico de un amplio abánico de productos era arrendada anualmente mediante adjudicación a la puja de mayor cuantía propuesta por distintos licitadores ${ }^{38}$. Estos arrendamientos permiten deslindar en dos la actividad de los linajes ciudadanos respecto a la fiscalidad municipal: por una parte pujaban para lograr la adjudicación de determinados capítulos impositivos, y por otra

${ }^{37}$ El precio de la colecta de la imposición dels draps de tall fue dedicado por entero a tal menester.Cfr. AMV Manuals de Consells A-21 (1399, enero 11).

${ }^{38}$ Los impuestos municipales en Valencia siempre fueron percibidos mediante mecanismos indirectos (mercaderia, tall del drap, carne, vino, aceite, pesca, pan; dels menjadors o molienda foránea, y tasas especiales arbitradas momentáneamente para armar naves y combatir piratas o corsarios) mientras que los impuestos reales fueron directos hasta su extinción. La peyta que gravaba el patrimonio vecinal fue suprimida en la ciudad de Valencia como recompensa de Pedro IV a su contribución y lealtad en la guerra de Castilla (13561365), y en las Cortes de 1364 el mismo monarca también la declaraba exenta del pago del morabati. 
regentaban magistraturas político-contables retribuidas con un salario ( $A d m i$ nistrador de les imposicions, Oidor de comptes, Racional, etc).

En 1358 Francesc Marrades junto a Miquel de Palomar compraron algunos capítulos impositivos por 60.000 sueldos. En 1364 Joan Suau fue colector de todas las especies salvo el pan y la carne. En 1377 Pere Suau comprador del tall del drap revendía la imposición a Bertomeu Badia, y el mismo año era parçoner en la imposició del blat. Al menos en 1378, 1379, 1380, 1385 , y 1389 Pere Suau compró la sisa de la carne. Pero la proyección sobre los arrendamientos fiscales superaban incluso el ámbito municipal, puesto que en 1376 y 1380 Pere Suau junto a Arnau Granell compraron els delmese vendes de pa e vi e d'oli e altres pertanyents a la mesa episcopal, y en 1386 y 1391 Joan y Bernat Suau de nuevo eran arrendadores del diezmo en la diócesis valenciana. Joan Suau en 1398 percibía un porcentaje de la peyta recaudada en Sagunto. Del mismo modo, Pere Marrades en 1399 arrendó el lugar de Espioca, una alquería del término ciudadano situada al noroeste, y poco después en 1400 junto a Lois Carbonell compró las rentas reales de la villa de Cullera por 275.000 sueldos, siendo usufructuario de las mismas hasta que en 1404 la ciudad de Valencia y la villa de Cullera redimieron la compra, devolviendo la cantidad con la emisión pertinente de censales municipales ${ }^{39}$.

Generalmente la constitución de compañías asociadas para la compra de los impuestos era inevitable y pretendía ofertar de entrada al municipio una parte de la cifra alcanzada. La dedicación continuada a esta actividad suponía el desembolso inmediato de una cantidad sustancial del valor cotizado por parte del arrendador, mientras que el resto se pagaba a lo largo de la anualidad conforme se recaudaba entre la población. El capital necesario para hacer frente a una cifra líquida de ese tamaño hacía necesaria la existencia de ciertos

39 Cfr. Los Marrades han recibido un tratamiento individualizado en un capítulo específico de Valencia municipio medieval. Poder político y luchas ciudadanas (1239-1418) En prensa. Las noticias de los arrendamientos realizados por los Suau han sido extractadas de los protocolos notariales de Bernat Costa conservados en el Archivo del Reino de Valencia, de las actas municipales y manuales de albaranes correspondientes. La ausencia y escasa continuidad de los libros de Claveria Comuna anteriores al siglo XV impiden conocer con exactitud a cuanto ascendió la cuantía pagada por la compra de estos impuestos. No obstante, a título indicativo y referencial el impuesto de la carne de 1365 se vendió por 21.695 sueldos, en 1391 por 190.000, y en 1393 por 156.000. La imposició del tall del drap de 1391 ascendió a 130.050 sueldos, y la de 1393 a 106.733 . L'imposició de l'almodí fue comprada en 1391 por 65.000, la dels blats de 1393 por 63.333, y la del vi del mismo año por 60.000. La cuantía de las tasas que gravaban los productos ascendía en 1390 a 6 dineros por libra en el vino al por menor, a dos en el vino al por mayor, a uno en la carne, a seis en los paños, a dos en la mercaderia y a seis en el cahiz de trigo. Cfr. E. VIDAL BELTRÁn, Valencia en la época de Juan I, Valencia, 1974, pp. 174-175. 
parsoners o compañeros asociados, que podían alcanzar el número de seis entre els principals compradors según las ordenanzas municipales ". En cualquier caso un personaje destacado debía quedar asignado como responsable y fiador ante la ciudad. La necesidad de la compañía o asociación también era necesaria para llevar a cabo la recaudación de todos los consumos arrendados a través de distintos colectores, cuyo objeto era perseguir intencionadamente el fraude para obtener los máximos beneficios mediante una pormenorizada administración contable. En este sentido ni los Marrades ni los Suau recaudaron directamente los derechos arrendados sino que utilizaron a sus socios o a terceros. Su dedicación política o la diversificada gama de negocios practicados se lo impedirían sobre todo porque el ejercicio de sindicaturas, embajadas o mensajerías, cuando no otros negocios municipales o privados (draperia, comercio, etc), harían imposible el seguimiento puntual y pormenorizado de la recaudación de los consumos. En estas circunstancias el patriciado recurría al subarrendamiento con lo que su papel quedaba limitado al de capitalista inversor, un intermediario especulador que se dedicaba tan sólo a recoger beneficios calculados ${ }^{41}$. El margen existente entre el precio de compra del impuesto y el valor real que se percibía tras gravar pormenorizadamente el tráfico y consumo del capítulo arrendado hacían previsibles los beneficios.

La actividad arrendataria de la fiscalidad municipal también coincide cronológicamente con el momento de desarrollo de su carrera política municipal, y constituye otro de los negocios de caracter semipúblico derivados del predominio político en la municipalidad. Así podemos comprobar que en 1416 Joan Suau junto a Joan Pujada y mossèn Francesc Martorell ejercen de reebedors e colectors de los impuestos de la Generalitat coincidiendo con el desempeño de cargos administrativos en esa institución. Esta circunstancia se puede ejemplificar con el caso de Pere Suau, quien desde 1389 ve truncada la continuidad en la ostentación de magistraturas, finaliza consiguientemente el arrendamiento impuestos, deja de abastecer los silos municipales y reduce ostensiblemente la percepción de intereses censales. El inicio de la decadencia de su trayectoria política es tal que los Suau dejan de ser electos en magistraturas renovables anualmente hasta 1405 , e incluso dejaron de ser nominados como consellers de ciutadans de parròquies hasta 1402 en el distrito donde tradicionalmente estuvieron arraigados (San Nicolás).

40 Cfr. AMV, Manuals de Consells A-16 (1374, diciembre 15).

${ }^{41}$ A finales de 1380 Pere Suau, comprador del capítulo de la carne de Valencia y su contribución para el año siguiente, vendía en subarrendamientos anuales y locales a distintos carniceros del término municipal el derecho de imposición correspondiente sobre Godella, el Grau, Benimaclet, Vinalesa, Almacera, Alboraya, Burjassot, Judería de Valencia, etc). Cfr. ARV, Protocolo 633 (Bernat Costa). 
El último arrendamiento de Pere Suau data de 1389 cuando junto a Mateu Manresa compraron el capítulo de la carne, recibiendo una de las ayudas institucionales habituales para sobreelevar su puja. Hasta entonces la conexión entre los negocios municipales y predominio en el gobierno ciudadano se fundamentaba en el prestigio político y económico. Así el descalabro político de los Suau condujo inexorablemente a la ruina de los negocios municipales. La quiebra de Pere Suau data de 1389 y fue acompañada del desmoronamiento de la carrera de todo el linaje, e incluso de la huida de Valencia ante el acoso de sus acreedores y enemigos. La inminente subasta de los bienes y la reclamación de la dote por su esposa ante el Justicia Civil sacaron a la luz pequeñas deudas, pero la ejecución sobre sus bienes tan sólo había de hacer frente a una cantidad ínfima, fácilmente solventable con las rentas censales percibidas del municipio $^{42}$. Pere Suau había huido sin abonar al municipio 13.730 sueldos en concepto de último plazo por el arrendamiento del impuesto de la carne, y en adelante la deuda sería anotada puntualmente en los libros de clavería hasta mucho después de su muerte.

La desaparición simultánea de la vida política municipal corrobora que la quiebra de los negocios tenían índole política. En efecto, el problema se remonta a la elección de los missatgers que en 1388 Valencia envió las cortes de Monzón convocadas por Juan I. En la delegación figuraban Pere Joan, micer Bonifaci Ferrer, Jaume Romeu, Berenguer de Rabinats y Joan Suau menor. Su intervención interesada en las Cortes daría lugar a que fuesen declarados traidores por los Jurats electos en 1389. La postura política que en nombre de la ciudad plantearon en Monzón los missatgers -enemistada con los consejeros más próximos de Juan I- daría pie a que el caporal del linaje tuviera que huir de Valencia puesto que la municipalidad se hallaba ahora en manos del partido rival encabezado por los Marrades. El 18 de septiembre de 1389 el Consell decidió iniciar un proceso de traición a los síndicos delegados a Cortes en el tribunal del Gobernador que se prolongaría hasta $1396^{43}$. El fin del proceso coincide precisamente con la defunción de Juan I y con la depuración de los consejeros del monarca difunto por el consejo de regencia. Los Centelles y los Arenós fueron desplazados entonces de la cámara real con el consiguiente triunfo del linaje Vilaragut, de modo que los Suau fueron rehabilitados y volvieron a desempeñar magistraturas municipales. La deuda

${ }^{42}$ Cfr. ARV, Justíia Civil. Demandes i oposicions 594 mano 2 fol. 37-44 y mano 6 fol. 40-47, también AMV, Manuals de Consells A-19 (1390, febrero 4), y E. Vidal Beltrán, op. cit., p. 210.

${ }_{43}$ Cfr. AMV, Manuals de Consells A-19 (1389, septiembre 18 y octubre 12). También M. Llop CatalÀ, Proceso de Bonifacio Ferrer, «Escritos del Vedat», 10 (Valencia, 1980), pp. 415-471. 
siguió vigente hasta 1408 pero ésta ya sólo constituía un problema administrativo ${ }^{44}$.

Desde principios del siglo XV el Consell estableció unas ordenanzas perpétuas en las que cualquier magistrado ciudadano -en especial Justícies, Jurats y Administradors de les imposicions- quedaban inhabilitados para arrendar los impuestos municipales, así como para importar grano a los silos municipales como caporales o parfoners, bajo la pena conminatoria de mil florines de oro, la exclusión del regimiento municipal y la pérdida del cargamento. ${ }^{45}$ En adelante la prohibición quedaría incluida en el compromiso juramentado que todos los oficiales municipales debían de profesar ineludiblemente al tomar posesión de su cargo. Todos los indicios apuntan a pensar que el patriciado estaba comenzando a gestar un mecanismo institucional que librara a la ciudad de banderías y luchas partidistas por el control de las finanzas. La Taula de Cambis de la ciutat de València fue creada el 15 de octubre de 1407 a imitación de la fundada en Barcelona en 1401, pero su primera etapa de existencia sería tremendamente breve y turbulenta ${ }^{40}$. Su fundación pretendía evitar los perjuicios institucionales derivados de las quiebras de cambistas, de la morosidad de los acreedores ciudadanos, de la parcialidad de los magistrados gobernantes, y sobre todo intentaba arbitrar una solución concordada entre los intereses patricios en pugna por el control de las finanzas municipales. En la Taula se habrían de concentrar todos los recursos y depósitos municipales (rentas, bienes y derechos) para solventar con una administración única todos'los gastos, argumentándose además que el sobrante de los balances anuales se dedicaría a amortizar cargas censales. No obstante, su funcionamiento administrativo era difícil si no imposible. En 1409 todavía no se habían presentado la contabilidad aclaratoria de su primera anualidad de existencia. Los gestores de la Taula

${ }^{44}$ Cfr. Marina Mitjà, Procés contra els consellers, domèstics i curials de Joan I, entre ells Bernat Metge, «BRABLB», 27 (Barcelona, 1957-1958) pp. 375-417. El proceso por deudas se prolongó todavía algún tiempo. Peyrone, viuda del difunto, intentaría componerse con la administación utilizando la vía de amigable arbitración mediante la designación de jueces delegados, pero el pleito subsiste en 1405, y aún sería heredado por Pere Suau menor hasta que en 1415 una nota marginal en los Manuals de Consells nos indica que el proceso había pasado a una jurisdicción superior.

4s Cfr. AMV, Manuals de Consells A-24 (1409 junio 3 y 1411 enero 28).

46 Las primeras noticias de la misma quedan recogidas en las actas municipales. Cfr. Idem A-23 (1407 octubre 20, 1408 enero 3 y febrero 10), A-24 (1409, mayo 10 y junio 9). Sobre la misma cfr. Salvador CARRERES ZACARÉs, La Taula de Cambis de València (14081719), Valencia, 1957, en especial pp. 7-15. 
(dos Regidors primero y un Tauleger después), nombrados directamente por los Jurats, no rendían las correspondientes cuentas porque costeaban con sus fondos todas las necesidades ciudadanas ordenadas por el ejecutivo sin razonar, certificar o restituir el gasto. Los descubiertos comenzaron a proliferar derivados de la relación política que ligaba a los administradores con una oligarquía patricia interesada en mantener buenas relaciones con la monarquía aún a costa de vaciar las arcas ciudadanas. La ruina de la banca municipal era inminente desde 1414. El acta de defunción de la Taula data de 1416 cuando el municipio se vió obligado a vender nuevos censales (por valor de cuatro mil florines) para cubrir los descubiertos y cerrar de forma contable su primer período de existencia. Su completa inoperancia financiera se justificaba por la injerencia política y partidista de los linajes patricios.

\section{RÉSUMÉ}

La déconnexion méthodologique entre l'histoire des institutions et l'histoire social et économique devient manifeste dans l'étude des biens, des finances et de la fiscalité, quand il devient indispensable de traiter l'ensemble dans le cadre générique de l'histoire du pouvoir. La conjonction entre l'oligarchie patricieene et les finances du Valencia médiéval, dérive du monopole que certains lignages citadins exercèrent sur le pouvoir municipal et de la projection politico-économique de ses intérêts de groupe sur l'administration publique. L'action politique et la projection financière de deux dynasties patriciennes, comme celle des Marrades ou des Suau, peuvent se suivre à la trace dans le strict contrôle qu'exercèrent les magistratures administratives, dans le financement de l'approvisionnement fromental, dans le recouvrement d'intérêts à charge de la dette censitaire municipale ou dans les mécanismes mêmes du recouvrement fiscal.

\section{SUMMARY}

The methodological disconnexion between institutions and social economic history becomes more and more patent in the study of properties, finances and tax systems, when it becomes indispensable to treat the whole according to the generical framework of power history.

The conjunction between patrician oligarchy and the finances of the medieval Valencia, derives from the monopoly that some city lineages exercised on the municipal power and from the politico-economic projection of group interests on the public administration. The political administration and the financial projection of two patrician dynasties, as well as that of the Marrades or the Suau, could easily be followed through the finance of wheat supply, through the collection of interests on the municipal debt or through the very collection mechanisms. 